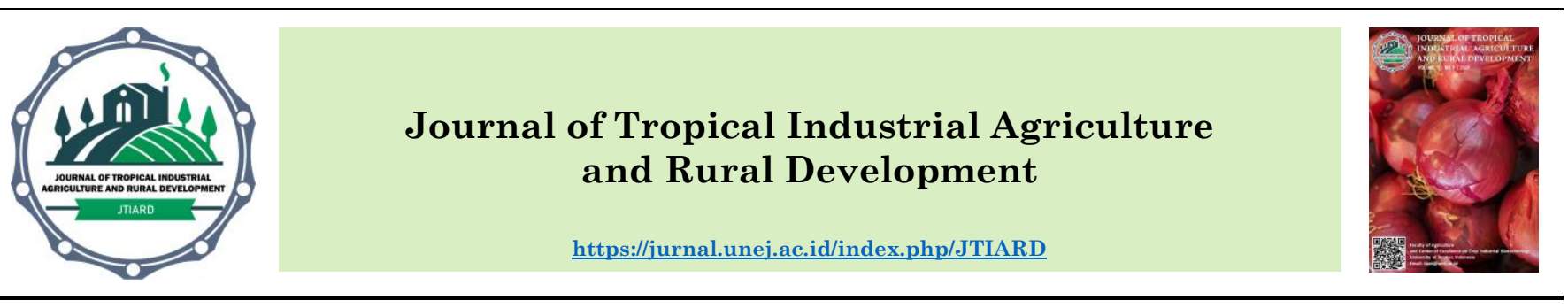

\title{
Increasing corn and soybean yields by arranging the plant spacing and NPK fertilizer dosages in intercropping system
}

\author{
Abdul Wahid Alqorni and Sigit Soeparjono *, \\ Agronomy Study Program, Faculty of Agriculture, University of Jember. Jl. Kalimantan 37 Kampus Tegalboto Jember \\ 68121
}

\begin{abstract}
Corn and soybean are food crops which are ranked on the second and third position as the main crops with the highest yield in Indonesia. Based on data of 2012, corn and soybean harvested areas amounted 3,956 ha and 597.65 ha with the productivity of 48.99 tons/ha and 843.15 tons/ha, these areas increased up to 4,388 ha (corn) and 589.42 ha (soybeans) which lead an increase in corn and soybean production by 52.85 tons/ha and 887.54 tons/ha. However, increasing crop productivity, especially for corn and soybeans, cannot continuously use land expansion because the land area of Indonesia that is suitable for agriculture is only 94.07 million ha from 188.20 million of total land area. Thus, the solution to overcome this issue is by arranging the plant spacing and providing proper nutrients. Plant spacing in intercropping systems can minimize competition between plants to provide a wellgrown of both plants. This research aimed to determine the increase in productivity of corn and soybean plants using intercropping systems through a combination of plant spacing and a combination of NPK fertilizer dosages. This study used a factorial experimental method that planted crops on the land with 2 factors with split-plot design of $4 \times 3$ factorial and 3 replications. The first factor is the combination of plant spacing with 4 levels, they were plant spacing of corn; $50 \mathrm{~cm} \times 40 \mathrm{~cm}$ $(\mathrm{J} 1), 75 \mathrm{~cm} \times 40 \mathrm{~cm}(\mathrm{~J} 2), 100 \mathrm{~cm} \times 40 \mathrm{~cm}(\mathrm{~J} 3), 125 \mathrm{~cm} \times 40 \mathrm{~cm}(\mathrm{~J} 4)$ and plant spacing of soybean; $40 \mathrm{~cm} \times 20 \mathrm{~cm}$. The second factor is 3 levels of NPK fertilizer dosages combination, they were $0 \%$ NPK fertilizer dose of the recommendation $\left(0 \mathrm{~g} / \mathrm{m}^{2}\right)(\mathrm{D} 1), 50 \%$ NPK fertilizer dose of the recommendation $\left(198.5 \mathrm{~g} / \mathrm{m}^{2}\right)$ (D2), $100 \%$ of NPK fertilizer dose of the recommendation $\left(397 \mathrm{~g} / \mathrm{m}^{2}\right)$ (D3), with 3 replications. DMRT test (Duncan, Multiple Range Test) was performed with a confidence level of $95 \%$ when the results between treatments were significantly different.
\end{abstract}

Keywords: Corn, Soybeans, Intercropping, Plant spacing, NPK Fertilizer

\section{ARTICLE INFO}

Corresponding Author:

Sigit Soeparjono

s.soeparjono@gmail.com

Received: February 7, 2020

Accepted: May 20, 2020

Published: June 10, 2020

DOI: $10.19184 /$ jtiard.v1i1.16403

\section{How to cite:}

Arqoni AW, S Soeparjono (2020). Increasing corn and soybean yields by arranging the plant spacing and NPK fertilizer dossages in intercropping system. J. Trop. Agric. Ind. Rural Dev. 1(1): 8-16 


\section{INTRODUCTION}

Food crops are all types of plants consumed by humans as energy intake used for survival. Corn and soybeans are the second and third most important food crops as the main food-producing crops in Indonesia. According to the Ministry of Agriculture of Republic of Indonesia (2016) the ups and downs in the productivity of corn and soybean are affected by harvested areas. Data from 2012 to 2016 showed that the expansion of harvested areas along with increased productivity of corn and soybean. In 2012, the harvested area of corn and soybean is 3,956 ha and 597.65 ha with the productivity of 48.99 tons/ha and 843.15 tons/ha, and an increase in a harvested area in 2016 amounted to 4,388 ha (corn) and 589.42 ha (soybeans) which lead an increase in corn and soybean production by 52.85 tons/ha and 887.54 tons/ha.

Increased food crop productivity, especially corn and soybeans, cannot be continuously carried out through land expansion, because according to Rukmana and Yudirachman (2014) land areas of Indonesia that are suitable for agriculture are only 94.07 million ha out of a total of 188.20 million ha land areas. Another problem is the conversion of arable land into settlements, which are estimated at 80 thousand hectares per year (BPS, 2013). One way to overcome this problem is by land intensification with intercropping system. According to Permanasari and Kastono (2012) intercropping is a planting system with two or more plants that are planted in relatively equal time with intermittent planting and certain plant spacing. The intercropping system is aimed at optimal use of production factors of limited land areas (Prasetyo et al., 2009). The benefits of intercropping are to facilitate maintenance, reduce the risk of crop failure, save on production facilities, as well as to increase land-use efficiency (Lingga et al., 2015).

The problem in the intercropping system is the competition between two plants in uptaking water, nutrients, light, and growing space, to overcome these issues, it is necessary to adjust the plant spacing and provide proper nutrients. Plant spacing in the intercropping system can minimize competition between plants to provide a better growth of both plants (Nurmas, 2011). According to Mayadewi (2007) the treatment of plant spacing on corn plants significantly affected the weight yield of corn cobs per plant of which too dense of spacing will interfere with the plant growth due to competition for nutrients, water, sunlight, and growing space of plants. Nutrient N, P, and K are essential elements needed by most plants to support each phase of plant growth and development. The application of NPK fertilizer may increase the vigor of corn and plants does not collapse easily (Titah and Purbopuspito, 2016). However, application $\mathrm{N}$ elements only will cause plants to fall easily, susceptible to pests, while $\mathrm{N}$ excess will reduce the quality of crop production (Pratikta et al., 2013).

Plants need balanced and complete fertilization to produce optimally. Considering the above description, research is needed to investigate the effect of plant spacing and NPK fertilizer dosages on corn and soybean in intercropping systems in order to increase corn and soybean yields. Therefore, we need research in increasing of corn and soybean yield by arranging the plant spacing and NPK fertilizer dosages in intercropping system.

\section{MATERIAL AND METHOD}

\section{Experimental design}

The study was conducted in October 2018 until January 2019, located in Agrotechno Park, Jubung Village, Sukorambi Sub-district, Jember District.

The research was arranged in a factorial consisting of 4 factors of plant spacing and 3 factors of NPK fertilizer dosage, using Split Plot Design (RPT) with 3 replications. Therefore, the number of plots as many as $4 \times 3=12$ experimental plots and repeated 3 times so that the testing unit becomes $4 \times 3 \times 3=36$ experimental units. The data obtained were then analyzed using an analysis of variance (ANOVA). The treatment of each factor used in the study is as follows: The first factor is the combination of spacing with 4 levels; plant spacing of corn $50 \mathrm{~cm} \times 40 \mathrm{~cm}(\mathrm{~J} 1), 75 \mathrm{~cm} \times 40 \mathrm{~cm}$ (J2), $100 \mathrm{~cm} \times 40 \mathrm{~cm}(\mathrm{~J} 3), 125 \mathrm{~cm} \times 40 \mathrm{~cm}(\mathrm{~J} 3) \mathrm{J} 4)$ and plant spacing of soybean of $40 \mathrm{~cm} \times 20 \mathrm{~cm}$. The second factor is 3 levels of NPK fertilizer dosages combination, they were $0 \%$ NPK fertilizer dose of the recommendation (0 g/m2) (D1), 50\% NPK fertilizer dose of the recommendation $(198.5 \mathrm{~g} / \mathrm{m} 2)$ (D2), $100 \%$ NPK fertilizer dose of the recommendation $(397 \mathrm{~g} / \mathrm{m} 2)$ (D3), with 3 replications. DMRT test (Duncan, Multiple Range Test) was performed with a confidence level of $95 \%$ when the results between treatments were significantly different. Observation variables for soybean were plant height, number of crop pods, number of seeds 
per plant, the weight of 100 soybean seeds, and weight of soybean seeds per plot, while for corn; the height of plants, the weight of cob per plant (grams), the weight of 100 seeds per plot (gram), the weight of corn kernels per plot.

\section{Soil property test}

Soil properties test was conducted at the beginning of the study to determine the initial nutrient content and soil fertility status. Soil properties test determined the chemical properties of the soil in the form of the availability of $\mathrm{N}, \mathrm{P}$, and $\mathrm{K}$ in the soil. The test was carried out at the Lablitkoka Laboratory Renteng, Rambipuji, Jember District. Soil sampling was done in a composite method by taking soil at 5 points of land with a depth of 0-30 cm then mixed evenly, 5 g soil was taken and put into an icebox for laboratory analysis.

\section{Land preparation}

Land preparation was done by land clearing, tillage, and making plots. Land clearing was done to remove weeds and other crop residues from the land. Tillage was carried out 2 weeks before planting using a tractor. Making 4 blocks and making 36 plots, 3 blocks for intercropping, and 1 monoculture block with a size of $4.25 \mathrm{~m} \times 1.7 \mathrm{~m}$. The distance between plots was $30 \mathrm{~cm}$ with a height of $30 \mathrm{~cm}$, while the distance between blocks was $50 \mathrm{~cm}$.

\section{Planting}

Planting of corn and soybean were carried out simultaneously with the plant spacing treatment $\mathrm{J} 1$ : the planting of corn $50 \mathrm{~cm} \times 40 \mathrm{~cm}, \mathrm{~J} 2: 75 \mathrm{~cm} \times$ $40 \mathrm{~cm}, \mathrm{~J} 3100 \mathrm{~cm} \times 40 \mathrm{~cm}, \mathrm{~J} 4: 125 \mathrm{~cm} \times 40 \mathrm{~cm}$ and the plant spacing of soybean is uniform to $40 \mathrm{~cm} \times$ $20 \mathrm{~cm}$ at all. Plant spacing on monoculture land for corn is $75 \mathrm{~cm} \times 40 \mathrm{~cm}$ and $40 \mathrm{~cm} \times 20 \mathrm{~cm}$ for soybean. Planting holes of soybean and corn were made using a tugal (traditional digger) with a depth of 3-5 cm. The number of seeds used for corn was 1-2 seeds per hole and 2-3 seeds per hole for soybeans.

\section{Fertilization}

Fertilizers were applied according to treatment with recommendations of NPK fertilizer on 300 $\mathrm{kg} / \mathrm{ha}$ corn and $250 \mathrm{~kg} / \mathrm{ha}$ of soybeans. in this study, fertilizer have been applied to corn and soybean plants with a treatment dose of (d1) $0 \%$ of recommendations $\quad\left(0 \mathrm{~g} / \mathrm{m}^{2}\right), \quad(\mathrm{d} 2) \quad 50 \%$ of recommendations $\left(198.5 \mathrm{~g} / \mathrm{m}^{2}\right), \quad(\mathrm{d} 3) \quad 100 \%$ of recommendations $\left(397 \mathrm{~g} / \mathrm{m}^{2}\right)$. Half of fertilizer was added at 15 DAP and another at 30 DAP. Application of fertilizer was done by sprinkling it evenly in plant rows and covered with soil, watering was conducted after fertilizer application.

\section{Plant maintenance}

Maintenance of plants was carried out through several activities in steps, such as watering, replanting, thinning, and controlling plantdisturbing organisms (weeds, pests, and diseases). Watering was done every 2 days according to weather conditions. Replanting is done one week after planting with planting material with the same growth. Thinning was done 2 weeks after planting by leaving a sturdy and healthy plant (uniform). Corn and soybean pest control, grasshopper and caterpillar were sprayed using Prevaton while leaf rust control was sprayed using Dithane M-45. Weed control was done once a week after planting seeds by pulling weeds or using a sickle.

\section{Harvesting}

Harvesting of soybean could be done when the pods have matured physiologically with brownishyellow pods and the leaves turn to yellow and dry (90\% of the population) at the age of 83-93 day after planting (DAP). Harvesting of corn was done at the age of 85-90 DAP, when corn kernels attached to the cob looked shiny and did not trace when it pressed with nails.

Table 1. Result of soil analysis

\begin{tabular}{cc}
\hline Nutrients soil & Content in 100 (grams) \\
\hline $\mathrm{N}$ & $0.20 \mathrm{~g}$ \\
$\mathrm{P}$ & $0.05 \mathrm{~g}$ \\
$\mathrm{~K}$ & $0.04 \mathrm{~g}$ \\
\hline
\end{tabular}




\section{Observation parameters}

Observation parameters for soybean were plant height, number of pods per plant, number of seeds per plant, the weight of 100 seeds, fresh weight of stover (grams), dry weight of stover (grams), and weight of soybean seeds per plot, while for plants corn; plant height, the weight of cobs per plant (gram), the weight of 100 seeds per plot (gram), the weight of corn kernels per plot and land equivalent ratio (LER).

\section{RESULTS}

The results of the variance analysis (not shown) indicates that there is an effect of the whole single factor and treatment combinations. The plant spacing treatment showed very significantly different on the parameter of the weight of soybean seeds per plot and weight of corn kernels per plot, then the results were significantly different on the weight parameters of 100 soybean seeds, the weight of 100 corn kernels. The treatment given has no significant results on the parameters of plant height, the number of pods, and the number of seeds of soybean, similar results has also been found in plant height and cob weight of corn. The factor of NPK fertilizer dosage showed very significantly different results on the parameters of the number of soybean pods, the weight of 100 soybean seeds, and weight of soybean seeds per plot, and showed significantly different results on the parameters of the weight of 100 soybean seeds, fresh weight of soybean stover, dry weight of soybean stover, plant height of corn, the weight of 100 corn kernels, but no significant difference in the parameters of soybean height, cob weight, corn kernels weight per plot. The treatment given has no significant results on the parameters of plant height, the number of pods, and the number of seeds of soybean, similar results has also been found in plant height and cob weight of corn.

The factor of NPK fertilizer dosage showed very significantly different results on the parameters of the number of soybean pods, the weight of 100 soybean seeds, and weight of soybean seeds per plot, and showed significantly different results on the parameters of the weight of 100 soybean seeds, fresh weight of soybean stover, dry weight of soybean stover, plant height of corn, the weight of 100 corn kernels, but no significant difference in the parameters of soybean height, cob weight, corn kernels weight per plot. The combination of plant spacing and NPK fertilizer application showed significantly different results on the parameters of the number of soybean seeds per plant and the height of corn plants.

\section{The effect of the interaction between plant spacing and NPK fertilizer dosages in intercropping systems on number of seeds per soybean plant}

Based on the results, the highest number of seeds per plant is in the J3D3 combination that was $107.25 \mathrm{~g} /$ plant, while the lowest is in the J4D1 treatment with only $71.08 \mathrm{~g} /$ plant (Table 2 ).

Based on the results, the highest plant height of corn is in J4D3 treatment with high of $252.14 \mathrm{~cm}$, while the lowest is in J1D1 treatment with high of $208.65 \mathrm{~cm}$ (Table 3 ).

\section{Effect of plant spacing on corn and soybean yields in intercropping system}

\section{Weight of 100 soybean seeds and seeds per plot}

The result shows that the treatment with plant spacing of $100 \times 40 \mathrm{~cm}$ produced the highest average weight of 100 soybean seeds which is $423.22 \mathrm{~g} /$ plant while the lowest yield obtained at plant spacing of $125 \times 40 \mathrm{~cm}$ with $13.58 \mathrm{~g} /$ plant Figure 1A). The result shows that the plant spacing of $75 \times 40 \mathrm{~cm}$ produced the highest average, which is $423.22 \mathrm{~g} / \mathrm{plot}$ while the treatment of $125 \times 40 \mathrm{~cm}$ obtained the lowest value of 370.56 g/plot (Figure 1B).

Table 2. Effect of the interaction between plant spacing and NPK fertilizer dosages on number of seeds per soybean plant

\begin{tabular}{|c|c|c|c|}
\hline \multirow{3}{*}{ Plant spacing } & \multicolumn{3}{|c|}{ Dose } \\
\hline & D1 & D2 & D3 \\
\hline & (0g/plot) & (198.5g/plot) & (397g/plot) \\
\hline $\mathrm{J} 1(50 \times 40 \mathrm{~cm})$ & $74.42 \mathrm{BC} \mathrm{a}$ & $72.83 \mathrm{~B} \mathrm{a}$ & $75.75 \mathrm{D} \mathrm{a}$ \\
\hline $\mathrm{J} 2(75 \times 40 \mathrm{~cm})$ & $74.92 \mathrm{~B} \mathrm{ab}$ & $72.50 \mathrm{~B} \mathrm{~b}$ & $90.58 \mathrm{~B} \mathrm{a}$ \\
\hline $\mathrm{J} 3(100 \times 40 \mathrm{~cm})$ & $81.9 \mathrm{~A} \mathrm{c}$ & $92.00 \mathrm{~A} \mathrm{~b}$ & $107.25 \mathrm{~A} \mathrm{a}$ \\
\hline $\mathrm{J} 4(125 \times 40 \mathrm{~cm})$ & $71.08 \mathrm{C} \mathrm{b}$ & $74.08 \mathrm{~B} \mathrm{ab}$ & $82.50 \mathrm{C} \mathrm{a}$ \\
\hline
\end{tabular}

Note: Capital letters (vertical) and lowercase letters (horizontal). Numbers followed by different letters in the same column show significant differences according to the DMRT test at $95 \%$ confidence level 
Table 3. Effect of the interaction between spacing and dose of fertilizer on plant height of corn

\begin{tabular}{cccc}
\hline \multirow{2}{*}{ Plant spacing } & \multicolumn{3}{c}{ Dose } \\
\cline { 2 - 4 } & $\begin{array}{c}\mathrm{D} 1 \\
\left(0 \mathrm{~g} / \mathrm{m}^{2}\right)\end{array}$ & $\begin{array}{c}\mathrm{D} 2 \\
\left(198.5 \mathrm{~g} / \mathrm{m}^{2}\right)\end{array}$ & $\begin{array}{c}\mathrm{D} 3 \\
\left(397 \mathrm{~g} / \mathrm{m}^{2}\right)\end{array}$ \\
\hline $\mathrm{J} 1(50 \times 40 \mathrm{~cm})$ & $208.65 \mathrm{~B} \mathrm{~b}$ & $218.07 \mathrm{C} \mathrm{ab}$ & $232.63 \mathrm{~B} \mathrm{a}$ \\
$\mathrm{J} 2(75 \times 40 \mathrm{~cm})$ & $226.77 \mathrm{~A} \mathrm{a}$ & $226.23 \mathrm{~B} \mathrm{a}$ & $236.07 \mathrm{~B} \mathrm{a}$ \\
$\mathrm{J} 3(100 \times 40 \mathrm{~cm})$ & $230.59 \mathrm{~A} \mathrm{a}$ & $221.51 \mathrm{BC} \mathrm{a}$ & $219.98 \mathrm{C} \mathrm{a}$ \\
$\mathrm{J} 4(125 \times 40 \mathrm{~cm})$ & $209.75 \mathrm{~B} \mathrm{~b}$ & $243.46 \mathrm{~A} \mathrm{a}$ & $252.14 \mathrm{~A} \mathrm{a}$ \\
\hline
\end{tabular}

Note: Capital letters (vertical) and lowercase letters (horizontal). Numbers followed by different letters in the same column show significant differences according to the DMRT test at $95 \%$ confidence level

\section{Weight of 100 corn kernels and corn kernels per plot}

The data shows that plant spacing of $125 \times 40$ $\mathrm{cm}$ produced the highest yield of $23.31 \mathrm{~g} / \mathrm{plant}$, while the $50 \times 40 \mathrm{~cm}$ treatment showed the lowest yield of $17.33 \mathrm{~g} /$ plant (Figure $2 \mathrm{~A}$ ). In addition, the result shows that in the treatment of space of $75 \times$ $40 \mathrm{~cm}$ produced the highest yield of $5.08 \mathrm{~kg} / \mathrm{plot}$, while in the treatment of $125 \times 40 \mathrm{~cm}$ produced the lowest by $3.27 \mathrm{~kg} / \mathrm{plot}$ (Figure 2B).

A

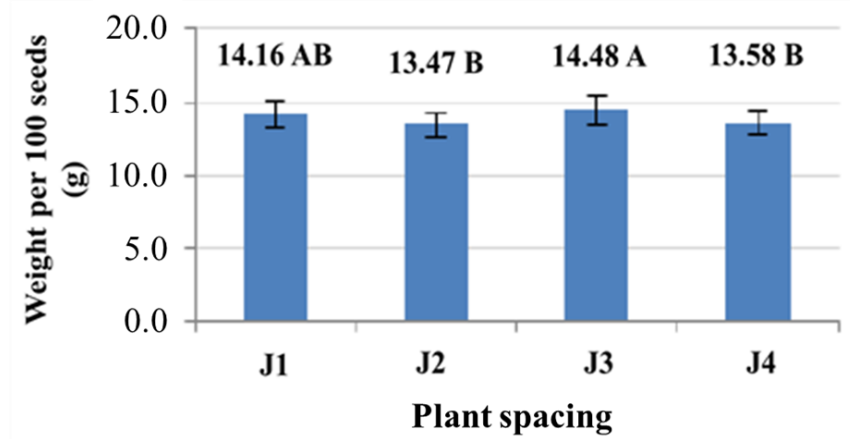

B

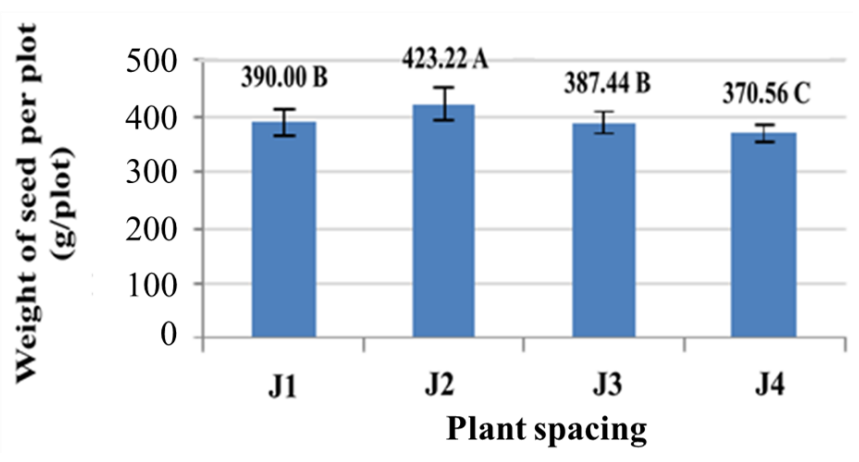

Figure 1. Effect of plant spacing on Weight of 100 soybean seeds (A) and weight of soybean seeds per plot (B)

\section{Effect of treatment with NPK fertilizer dosage on corn and soybean yields in intercropping system}

Effect on corn. The result shows the treatment of fertilizer with a dose of $397 \mathrm{~g} / \mathrm{plot}$ produced the highest average weight of corn kernels of $22.34 \mathrm{~g} / \mathrm{plant}$, while the NPK fertilizer treatment of $0 \mathrm{~g} / \mathrm{plot}$ showed the lowest yield with an average weight of $19.32 \mathrm{~g} / \mathrm{plant}$ (Figure 3).

Effect on soybean. The data shows that the dose of $397 \mathrm{~g}$ fertilizer/plot obtained the highest yield on the average number of pods that is 57.08 $\mathrm{g} /$ plant while those treated with the dose of fertilizer $0 \mathrm{~g} / \mathrm{plot}$ suggests the lowest results of $45.48 \mathrm{~g} / \mathrm{plant}$ (Figure 4A). Data also shows the fertilizer dosage treatment of $189.5 \mathrm{~g} / \mathrm{plot}$ produced the highest value of $14.53 \mathrm{~g} / \mathrm{plant}$ while the treatment of $0 \mathrm{~g} / \mathrm{plot}$ produced the lowest value of $13.18 \mathrm{~g} / \mathrm{plot}$ (Figure 4B). The data shows that the treatment with a dose of $397 \mathrm{~g} / \mathrm{plot}$ produced the highest average weight of soybean seeds per plot which is $424.91 \mathrm{~g} / \mathrm{plot}$ while the treatment $0 \mathrm{~g} / \mathrm{plot}$ produced an average value of $368.12 \mathrm{~g} /$ plot (Figure $4 \mathrm{C})$.
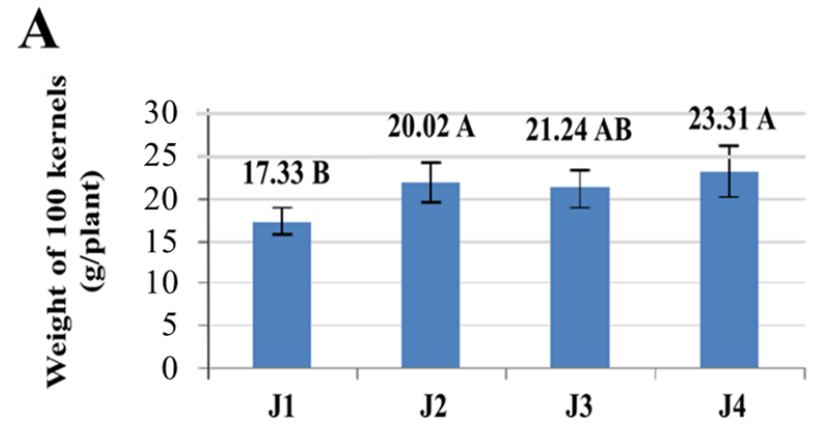

Plant spacing

B

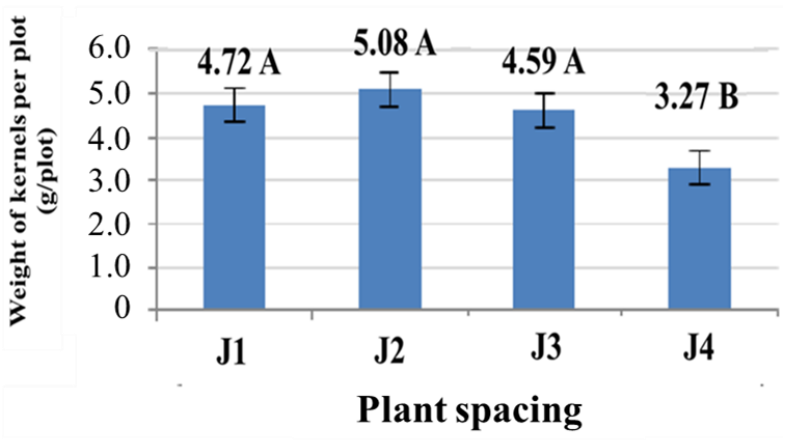

Figure 2. Effect of plant spacing on the weight of 100 cord seeds (A) and corn weight per plot (B) 


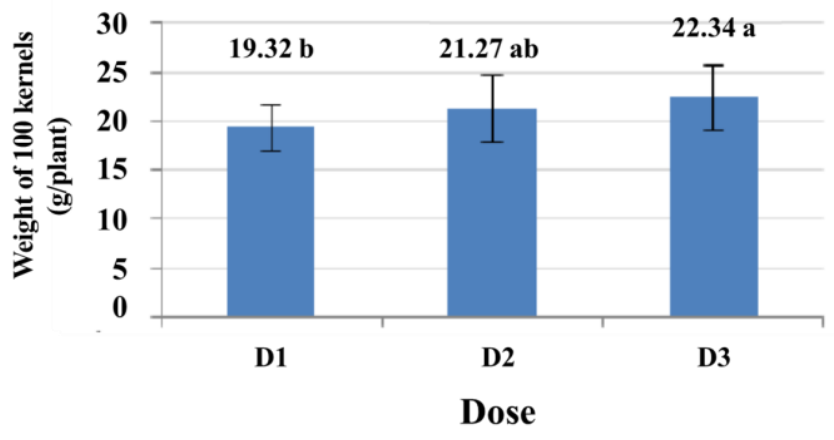

Figure 3. Effect of NPK fertilizer dosages on the number of kernels

\section{DISCUSSION}

For the parameters of the number of soybean seeds per plant, the treatment with the highest number of seeds was J3D3 with plant spacing of corn is $100 \mathrm{~cm} \times 40 \mathrm{~cm}$ and $40 \mathrm{~cm} \times 20 \mathrm{~cm}$ for soybeans with NPK fertilizer dosage $397 \mathrm{~g} / \mathrm{plot}$ was 107.25 seeds while treatment with the lowest average number of soybean seeds per plant was J4D1 of 71.08 seeds (Figure). These results indicated that J3D3 produced the highest average number of seeds, this is because the formation of seeds in soybean plants is influenced by the availability of nutrients, water, sunlight, spacing, and cultivation method. The spacing of J3D3 treatment might be in accordance with the needs of soybeans to form seeds. plant spacing with too tight and too wide will affect the yield of soybeans, of which too tight plant spacing leads a competition between plants, however, too wide plant spacing will affect yields per unit land. In addition, plant spacing that is too wide in the intercropping system will be easily overgrown by weeds thus may be a competitor in obtaining nutrients, besides potentially to be a nesting site for plant pests and cultivated plants are more susceptible to plant-disturbing organisms.

The number of seeds per plant is also influenced by the availability of nutrients in the soil. Muharam (2017) explained that the seed formation phase is a critical phase for plants, where plants need nutrients in sufficient amounts to stimulate a perfect development. Lacking or excessive nutrients will result in the unperfect filling of seeds. During the filling process, $\mathrm{N}$ and $\mathrm{P}$ play essential roles. The availability of sufficient and balanced $\mathrm{N}$ elements influences the formation of protein and amino acids during the process of seed formation which leads to fully filled seeds (Permanasari et al., 2014). When the plant reaches the generative phase, $\mathrm{P}$ element is required in greater amounts than that of the vegetative phase, thus during the phase of seed formation, soybean requires high amounts of $\mathrm{P}$ element (Supriyadi et al 2014). In the combination of J3D3, the soybean plants are able to uptake sufficient light and nutrients during the filling phases of the seeds, especially the $\mathrm{P}$ element because corn may help maximize the availability of the $\mathrm{P}$ element that could be absorbed by the soybean plants. Through the presence of mycorrhiza at the root of corn. Mycorrhiza is able to encode organic acids and phosphatase enzymes and change $\mathrm{P}$ elements that are difficult to absorb by plants into elements that are easily absorbed by plants (Charisma et al., 2012). Therefore, the intercropping system of corn plants has a good impact on the availability of element $\mathrm{P}$ for soybeans.

Plant height of corn is associated with growth or increasing size and number of cells of plants in the vegetative phase. Parameters of Plant height were observed when corn at 42 days after planting. According to Ekowati and Mochaman (2011), observations of plant height were carried out as
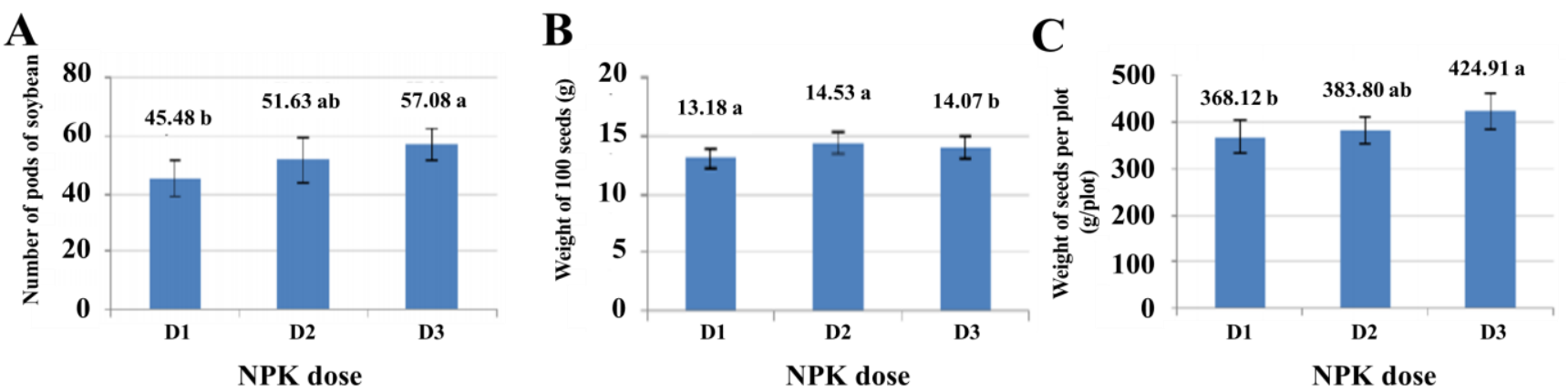

Figure 4. Effect of NPK fertilizer dosages on the number of soybean pods (A), weight of 100 seeds (B), and weight of seed per plot (C) 
indicators of growth to measure the effects of environmental factors and the treatment given to plants. Based on the previous research, the height of corn is influenced by both treatments, which are spacing and NPK fertilizer application. Plant spacing and plants population on certain land units will determine competition between plants and will affect the growth and development of intercropped plants (Susanti et al 2016). Sucipto (2009) mentioned that competition occurred when plants compete with each other and affecting the growth factors such as light, water, nutrients, and others.

For parameters of the weight of 100 seeds, significantly different of yields were found at plant spacing J3 $(100 \mathrm{~cm} \times 40 \mathrm{~cm}$ for corn and $40 \mathrm{~cm} \times$ $20 \mathrm{~cm}$ for soybeans), this treatment provides the highest average soybean seeds weight per plant of $14.48 \mathrm{~g}$. The treatment of wider plant spacing allows plants to obtain more nutrients, sunlight, and water as well as less possibility of competition between plants. In this study, J3 treatment obtained a higher average for the weight of 100 soybean seeds, it might be because at the density level of the J3 treatment, soybean plants are able to optimize the nutrients, sunlight, and water for the formation and development of soybean seeds. This data suggested that the expansion of plant spacing to a certain level still able to provide good results. According to Sembiring et al. (2015) if the increase of plant density is still below the level of increased competition, then an increase in yield will be achieved at denser plant spacing.

Seed development is influenced by several factors, such as the availability of nutrients, and the environment (light and humidity). According to Yuwariah et al. (2017), the development of seeds of plants is influenced by several factors, such as the availability of nutrients, sunlight, and environmental humidity. Based on Table 2, the weight parameters of 100 corn seeds showed significantly different in the single parameter of spacing. The best yield of treatment was obtained in $\mathrm{J} 4$ treatment with a yield of $23.31 \mathrm{~g} /$ plant, while the lowest yield was J1 treatment which only reached an average yield of $17.33 \mathrm{~g}$, this is in line with other parameters that showed $\mathrm{J} 1$ is a not good treatment.

For parameters on the weight of corn per plot, J2 treatment showed the highest results with 5.08 $\mathrm{kg} / \mathrm{plot}$. This is because this treatment allows sufficient distance between plants so that the population in one plot is quite high compared to $\mathrm{J} 3$ and J4. According to Aisyah and Herlina (2018), the wider plant spacing will have a greater dry weight of the crib, but the number of plants per plot is smaller so that the number of cobs and seeds is also small. The $\mathrm{J} 1$ treatment is slightly lower weight of corn per plot than that of J2, this indicated that the treatment of $\mathrm{J} 1$ is too tight so that even though the number of plants is higher, competition between plants is also higher which results in a decrease yield of corn weight per plot.

Based on Table 2. the effect of NPK fertilizer showed very significantly different for the parameter of the number of pods, but the plant spacing treatment showed no significant differences. Figure 5 . shows that the best treatment is NPK fertilizer with a dose of 397 $\mathrm{g} /$ plot (D3) with yield (57.08 g/plant) while the lowest yield on the number of pods per soybean plant was at NPK fertilizer with a dose of $0 \mathrm{~g} / \mathrm{plot}$ with $45.48 \mathrm{~g} /$ plant.

According to Samuli et al. (2012) the addition of fertilizers to plants, especially the $\mathrm{P}$ element, may accelerate the harvesting period of plants thereby providing a better number of pods. This observation parameter showed an increase in the number of pods of soybean per additional unit of NPK fertilizer. This result suggested that the addition of NPK fertilizer may improve soil properties whether biology, physics, or soil chemistry so that soil fertility is increased and the availability of $\mathrm{N}, \mathrm{P}, \mathrm{K}$ nutrients in the rhizosphere for pod formation is sufficient.

The parameters on the weight of 100 soybean seeds showed a very significant effect on the NPK fertilizer dosage treatment. The best treatment was found in D2 with an average yield of $14.57 \mathrm{~g}$ while the lowest treatment was D3 with an average yield of $13.92 \mathrm{~g}$. Excessive application of fertilizer can actually reduce crop yields because there will be nutrient residues in the soil. According to Wulandari (2016) application of too much fertilizer to the plant results in more concentrated nutrients and difficult to be uptake by plants.

The NPK fertilizer dosage treatment has a very significant effect on the weight of soybean seeds per plot. The application of NPK fertilizer may increase the ability of the soil to provide nutrients for soybean to grow to the maximum, especially in the generative phase of which plants focus on the formation of plant parts for harvest such as the formation and filling of soybean seeds. The yield of seeds per unit area (productivity) and soybean 
seed quality can be optimal if the availability of nutrients is fulfilled, one of which is the $\mathrm{P}$ element which can stimulate plant growth in the generative phase (Rasyid, 2013). Based on Figure 8 , the treatment of NPK fertilizer dosages provides different results to the weight of 100 corn kernels. NPK fertilizer with dose of $397 \mathrm{~g} / \mathrm{plot}$ (D3) showed significantly different results with the treatment dosage of fertilizer $0 \mathrm{~g} / \mathrm{plot}$ (D1) but not different with NPK fertilizer dose of $198.5 \mathrm{~g} / \mathrm{plot}$. These results indicated that the addition of NPK fertilizer with a dose of $397 \mathrm{~g} / \mathrm{plot}$ of soil could improve the ability of the soil to provide nutrient needs of plants, especially when corn plants enter the generative phase which is very sensitive to the availability of nutrients in the soil.

During generative phase, corn needs enough nutrients to form parts of corn that are related to corn yields, such as corn cobs formation and corn kernels filling. In the vegetative phase especially when corn plants enter the seed filling period, nutrient uptake will increase more rapidly. The $\mathrm{P}$ and $\mathrm{N}$ elements will be continuously uptake by the plant until they are ripe, while the $\mathrm{K}$ element will be absorbed during the plant is silking (Sirappa and Razka, 2010).

\section{REFERENCES}

Aisyah Y, N Herlina. 2018. Pengaruh jarak tanam tanaman jagung manis (Zea mays L. var. saccharta) pada tumpangsari dengan tiga varietas tanaman kedelai (Glycine max (L.) Merrill). Produski Tanaman 6(1): 3-6.

BPS (Badan Pusat Statistik). 2013. Sensus Pertanian 2013. Jakarta (ID): Badan Pusat Statistik.

Charisma AM, YS Rahayu, Isnawati. 2012. Pengaruh kombinasi kompos Trichoderma dan Mikoriza Vesikular Arbuskular (MVA) terhadap pertumbuhan tanaman kedelai (Glycine max (L.) Merill) pada media tanam tanah kapur. LenteraBio 1(3): 1-4.

Ekowati D, N Mochamad. 2011. Pertumbuhan tanaman jagung (Zea Mays L.) varietas Bisi-2 pada pasir reject dan pasir asli di Pantai Trisik Kulonprogo. Manusia dan Lingkungan 18(3): 220-231.

Lingga GK, S Purwanti, Toekidjo. 2015. Hasil dan kulitas benih kacang hijau (Vigna radiata (L.) Wilczek) tumpangsari barisan dengan jagung manis (Zea mays kelompok Saccharata) Vegetalika. 4(2): 39-47.

Mayadewi NNA. 2007. Pengaruh jenis pupuk kandang dan jarak tanam terhadap pertumbuhan gulma dan hasil jagung manis. Agritrop 26(4): 153-159.

Muharam. 2017. efektivitas penggunaan pupuk kandang dan pupuk organik cair dalam meningkatkan pertumbuhan dan hasil tanaman kedelai (Glycine max
L.) varietas anjasmoro di tanah salin. Agrotek Indonesia 2(1): 44-53.

Nurmas A. 2011. Kajian waktu tanam dan kerapatan tanaman jagung sistem tumpangsari dengan kacang tanah terhadap nilai LER dan indeks kompetisi. Agriplus 21(1): 61-67.

Permanasari I, D Kastono. 2012. Pertumbuhan tumpangsari jagung dan kedelai pada perbedaan waktu tanam dan pemangkasan jagung. Jurnal Online Agroteknologi 3(1): 13-20.

Permanasari I, M Irfan, Abizar. 2014. Pertumbuhan dan hasil kedelai (Glycine max (L.) Merill) dengan pemberian Rhizobium dan pupuk urea pada media gambut. Jurnal Online Agroteknologi 5(1): 29-34.

Prasetyo, EI Sukardjo, H Pujiwati. 2009. Produktivitas lahan dan NKL pada tumpang sari jarak pagar dengan tanaman pangan. Akta Agrosia 12(1): 51-55.

Pratikta D, S Hartatik, KA Wijaya. 2013. Pengaruh penambahan pupuk NPK terhadap produksi beberapa aksesi tanaman jagung (Zea mays L.). Berkala Ilmu Petanian 1(2): 19-21.

Pusat Data dan Sistem Informasi Pertanian. 2016. Outlook Komoditas Pertanian Tanaman Pangan Jagung. Jakarta (ID): Kementerian Pertanian.

Rasyid H. 2013. Peningkatan produksi dan mutu benih kedelai varietas hitam unggul nasional sebagai fungsi jarak tanam dan pemberian dosis pupuk P. Jurnal Gamma 8(2): 46-63.

Rukmana R, HH Yudirachman. 2014. Kiat Sukses Budi Daya Bengkuang. Yogyakarta (ID): Lily Publisher.

Samuli LO, L Karimuna, L Sabaruddin. 2012. Produksi kedelai pada berbagai dosis bokasi kotoran sapi. Jurnal Penelitian Agronomi 1(2): 145-147.

Sembiring ASB, J Ginting, FE Sitepu. 2015. Pengaruh populasi kacang tanah (Arachis hypogaea L.) dan jagung (Zea mays L.) terhadap pertumbuhan dan produksi pada sistem pola tumpang sari. Jurnal Online Agroteknologi 3(1):52-71.

Sirappa MP, N Razak. 2010. Peningkatan Produktivitas Jagung Melalui Pemberian Pupuk N, P, K dan pupuk Kandang pada Lahan Kering di Maluku. [Prosiding] Pekan Serelia Nasional.

Sucipto. 2009. Dampak pengaturan baris tanam jagung (Zea Mays L.) dan populasi kacang hijau (Phaseolus radiates L.) dalam tumpangsari terhadap pertumbuhan dan hasil kacang hijau, jagung. Agrovigor. 2(2): 67-78.

Supriyadi S, Hartati, A Aminudin. 2014. Kajian pemberian pupuk $\mathrm{P}$, pupuk mikro dan pupuk organik terhadap serapan P dan hasil kedelai (Glycine max L.) varietas kaba di inseptisol Gunung Gajah Klaten. Caraka Tani 29(2):81-86.

Susanti S, Anwar, E Fuskhah, Sumarsono. 2014. Pertumbuhan dan nisbah kesetaraan lahan (Nkl) Koro Pedang (Canavalia ensiformis) dalam tumpangsari dengan jagung (Zea mays). Agromedia 32(2): 38-42. 
Titah T, Purbopuspito J. (2016). Respon pertumbuhan jagung terhadap pemberian pupuk NPK, Urea, SP-36, dan KCL. Eugenia 22(2): 62-69.

Wulandari W, Idwar, Murniati. (2016). Pengaruh pupuk organik dalam mengefisenkan pupuk nitrogen untuk pertumbuhan dan produksi tanaman bawang merah (Allium ascalonicum L.). JOM FAPERTA 3(2): 1-6

Yuwariah Y, Ruswandi D, Irwan AW. (2017). Pengaruh pola tanam tumpangsari jagung dan kedelai terhadap pertumbuhan dan hasil jagung hibrida dan evaluasi tumpangsari di Arjasari Kabupaten Bandung. Kultivasi 16(3): 514-521. 